\title{
Identification and Purification of Antimicrobial Lectins from Marine Crab Protunus pelagicus (Linneus, 1775)
}

\author{
Selvaraj Chidhambaradhas ${ }^{1 *}$, Thankaiah Selva Mohan², \\ Stanislaus $^{2}$ and Mary Josephine punitha ${ }^{1}$
}

\author{
${ }^{1}$ Department of Zoology, Centre of Marine Science and Technology, M.S. University, \\ Rajakkamangalam, Tamil Nadu, India \\ ${ }^{2}$ Department of Zoology, Rani Anna Government College, Tirunelveli -627008, \\ Tamil Nadu, India \\ *Corresponding author
}

\section{Ke y w o r d s \\ Protunus pelagicus \\ Lectins, \\ Klebsiella pneumonia, STI, AMPs, MIC, LBB. \\ Article Info \\ Accepted: \\ 26 May 2017 \\ Available Online: \\ 10 June 2017}

\section{A B S T R A C T}

Lectins are glycoproteins have the ability to bind carbohydrates. They are involved in biological process such as recognition and binding of carbohydrates, interactions of pathogens, apoptosis, etc. Lectins of different carbohydrate specificities are able to promote growth inhibition or death of bacteria and fungi. In the present investigation made to isolation, identification and antimicrobial activity of lectins from haemolymph of $P$. pelagicus. The haemolymph of Portunus pelagicus contains a protein, Portunus pelagicus lectins (PPL). The antimicrobial activity of the PPL was tested against six bacterial strains is Gram positive bacteria Staphylococcus aureus, and Gram negative bacteria Escherichia coli, Pseudomonas aeruginosa, Klebsiella pneumonia, Bacillus subtilis and Enterococcus faecalis. Among the six strains the maximum diameter of inhibition zone was recorded in Staphylococcus aureus and Pseudomonas aeroginosa and lowest diameter of inhibition zone was observed in Enterococcus faecalis. It indicates that, the haemolymph of crabs would be a good source of antibacterial agents.

\section{Introduction}

Lectins are carbohydrate binding proteins have the ability to induce cell agglutination or the precipitation of glyco-conjugates on cell surface receptors. Initially lectins were found and described in plants, later it were isolated from animals and also from microorganisms. However, the yields are usually extremely low. Lectins are glycoprotein have the ability to bind carbohydrates. They are involved in biological process such as recognition and binding with carbohydrates, interactions with pathogens, cell to cell communication, apoptosis, cancer metastasis and differentiation. The antibacterial, antifungal and antiviral activities of lectins have been reported (Boyel et al., 1997 and Singh et al., 2014). Lectins have become the focus of intense interest for biologists and in particular for the research and application in agriculture and medicine (Movafagh et al., 2013). Lectins 
of different carbohydrate specificities are able to promote growth inhibition or death of bacteria and fungi. The inhibition of fungi growth can occur through lectins binding to hyphae resulting poor absorption of nutrients as well as by interference on spore germination process (Lis and Sharon, 1981). Lectins are potential drugs for treatment of AIDS. Lectins (D-mannose-specific) can able to inhibit fusion of HIV infected cells with CD4 cells by a carbohydrate specific interaction with the HIV infected cells (Hansen et al., 1989).

Since ancient time, countries like China, Europe and India, used marine organisms for medicinal purposes. Marine invertebrates are rapidly synthesized an antimicrobial peptides (AMPs). It is a major component of innate immune defence system in marine invertebrates. Portunus pelagicus is a medium sized (CL males: $7 \mathrm{~cm}$, females: $6.5 \mathrm{~cm}$ ) nocturnal marine crab, greenish brown carapace with irregular pale mottling edged dark brown colour. Broad carapace has transverse granulate lines. It is an active swimmer, but during inactive periods buried in sediment. It is the most important edible crab, and a valuable component of small scale coastal fisheries in many countries in tropics (Batoy et al., 1980; Joel and Raj 1987; Mgaya et al., 1999). Hudson and Lester (1994) reported that, the crab has close contact with pathogenic bacteria and are prone to infection by microbes at various stages of growth. Cole, (2005) suggested that, AMPs can inhibit the spread of STI and HIV. In the present investigation made to isolation, identification and antimicrobial activity of lectins from haemolymph of P.pelagicus.

\section{Materials and Methods}

\section{Collection of experiment animal}

Portunus pelagicus were collected from the sea shore area along the Managudi estuary region at Kanyakumari district. They are transported to laboratory with care and kept in cement tank with sea water until further use. Each animal was subjected to a single bleed collection at the time of use. During sample collection time, walking legs of the crab was cutting with a fine sterile scissor and collect approximately 3-4 $\mathrm{ml}$ haemolymph in a sterile vessel, which contains sodium citrate buffer, $\mathrm{pH} 4.6$ and equal volume of physiological saline $(0.85 \% \mathrm{NaCl}, \mathrm{w} / \mathrm{v})$. It will prevent degranulation and coagulation of haemocytes. Centrifuge the sample at $10,000 \mathrm{rpm}$ at $4^{\circ} \mathrm{Cfor}$ 10 minutes. The haemocytes were precipitated and the supernatant were collected by aspirating and stored at $4{ }^{\circ} \mathrm{C}$ until used. The protein content of the haemolymph and other fractions was estimated by the method of Bradford using BSA as the standard (Brandford, 1976).

\section{Microbial strains and culture}

Gram positive bacteria Staphylococcus aureus, Bacillus subtilis and Enterococcus faecalis and Gram negative bacteria Escherichia coli, Pseudomonas aeruginosa and Klebsiella pneumoniae, were obtained from the C.S.I Kalyani Multi Specialty Hospital, Mylopore, Chennai. The organisms were grown in laboratory at $37^{\circ} \mathrm{C}$ for use for antimicrobial activity.

\section{Antibacterial assay}

The spectrum of antimicrobial activity was studied by using the techniques described by Bauer et al., (1996). Take $14 \mathrm{ml}$ of bacterial underlay of $1 \%$ agarose in $10 \% \mathrm{MH}$ broth supplemented with $0.02 \%$ Tween in a 12 X 12 $\mathrm{cm}$ petri dish. The agar was seeded with $1 \mathrm{x}$ $10^{6}$ washed bacteria. Wells of $3 \mathrm{~mm}$ diameter were punched into the agarose and $50 \mu \mathrm{l}$ of the test sample was pipetted into each. Sterile deionized water containing $0.1 \%$ acetic acid used as control. The plats were incubated at $4^{\circ} \mathrm{C}$ for 3 hours and then overlaid with $14 \mathrm{ml}$ 
of sterile $1 \%$ of agarose containing double strength LBB (Luria-Bertani Broth). They were further incubated 24 hours at $39^{\circ} \mathrm{C}$. Antimicrobial activity was expressed in terms of diameter of zone of inhibition was measured by using scale and recorded in millimetre.

\section{SDS-polyacrylamide gel electrophoresis}

According to the method of Laemmli, (1970) the agglutinin was performed by electrophoresis in $10 \%$ polyacrylamide gel under non denaturing condition at $\mathrm{pH}$ 8.9. The band was visualized by $0.2 \%$ Coomassie brilliant blue (G 250) staining followed by destaining in 5\% acetic acid containing $20 \%$ methanol. The sample was treated with $1 \%$ SDS in the presence or absence of 2mercaptoethanol for 5 minutes at $100^{\circ} \mathrm{C}$. The molecular mass of the purified Portunu spelagicus lectins (PPL) calculated according to the relative mobility with the Precision plus Protein standard.

\section{Mass spectrometry analysis}

The molecular mass was determined by ESI on a Q-ToF2 mass spectrometer (micromass) using sinnapinic acid as the matrix.

\section{Results and Discussion}

\section{Molecular characterization of Protunus pelagicus Lectins (PPL)}

The lectins PPL was purified from the haemolymph of Protunus pelagicus and the electrophoretic analysis analyses using SDSPAGE and IEF gels were performed. A single protein band corresponding to a molecular mass of approximately $27.0 \mathrm{KDa}$ (Fig. 1) was observed in SDS-PAGE stained with $0.2 \%$ Coomassie brilliant blue (G 250). PPL was observed as a single peak when applied to an anion exchange. The haemolymph of Protunus pelagicus contains a protein,
Protunus pelagicus lectins (PPL).The antimicrobial activity of the PPL was tested against six bacterial strains namely, Staphylococcus aureus, Bacillus subtilis and Enterococcus faecalis, Escherichia coli, Pseudomonas aeruginosa, Klebsiella pneumonia, are summarized in tables 1 and 2 . Among the six strains the maximum diameter of inhibition zone was recorded in Staphylococcus aureus and Pseudomonas aeruginosa and lowest diameter of inhibition zone was observed in Enterococcus faecalis.

Protunus pelagicus is an edible marine crab found in different coastal environment. The environmental factors cause morphological, physiological variations and diversity. Marine invertebrates are rapidly synthesized an antimicrobial peptides (AMPs) as a major component of innate immunity. These molecules have a molecular weight of $\leq 10$ $\mathrm{KDa}$, are the first line of host defence in various species. AMPs have microbicide properties against various clinical pathogens including the sexually transmitted infection (STI) causing Treponema pallidum, Chlamydia trachomatis and HIV (Yedety and Reddy, 2005). In the present study, the extract of $P$. pelagicus haemolymph showed antimicrobial activity against both Gram positive and Gram negative bacteria. A similar result was observed in a haemocytes of Indian mud crab Scylla serrata by Roshan Dinesh Yedery et al., (2009) and a marine crab $O$. macrocera haemolymph by Ravichandran et al., (2010). The antimicrobial activity of the PPL was tested against six bacterial strains is summarised in tables. Among the six strains the maximum diameter of inhibition zone $(21 \mathrm{~mm})$ was recorded in Staphylococcus aureus and Pseudomonas aeroginosa and lowest diameter of inhibition zone $(10 \mathrm{~mm})$ was observed in Enterococcus faecalis. The haemolymphs are the wonderful resource of antibacterial proteins. 
Table.1 Antimicrobial activity of the haemolymph of Protunus pelagicus

\begin{tabular}{|c|c|c|c|}
\hline s.no & $\begin{array}{c}\text { Concentration } \\
\text { of lectins }(\mu \mathrm{g})\end{array}$ & Organisms & Zone of inhibition \\
\hline 1 & 10 & Staphylococcus aureus & $7 \pm 3.01$ \\
\hline 2 & 13 & Staphylococcus aureus & $11 \pm 1.27$ \\
\hline 3 & 16 & Staphylococcus aureus & $15 \pm 2.10$ \\
\hline 4 & 19 & Staphylococcus aureus & $18 \pm 1.10$ \\
\hline 5 & 24 & Staphylococcus aureus & $21 \pm 3.21$ \\
\hline
\end{tabular}

Table.2 Antimicrobial activity of the haemolymph of Protunus pelagicus

\begin{tabular}{|c|c|c|c|}
\hline s.no & $\begin{array}{c}\text { Concentration } \\
\text { of lectins }(\mu \mathrm{g})\end{array}$ & Organisms & Zone of inhibition \\
\hline 1 & 10 & Pseudomonas aeruginosa & $8 \pm 1.02$ \\
\hline 2 & 13 & Pseudomonas aeruginosa & $12 \pm 1.15$ \\
\hline 3 & 16 & Pseudomonas aeruginosa & $17 \pm 1.25$ \\
\hline 4 & 19 & Pseudomonas aeruginosa & $19 \pm 2.30$ \\
\hline 5 & 24 & Pseudomonas aeruginosa & $21 \pm 1.15$ \\
\hline
\end{tabular}

Fig.1 SDS - gel electrophoresis of purified lectins from Protunus pelagicus

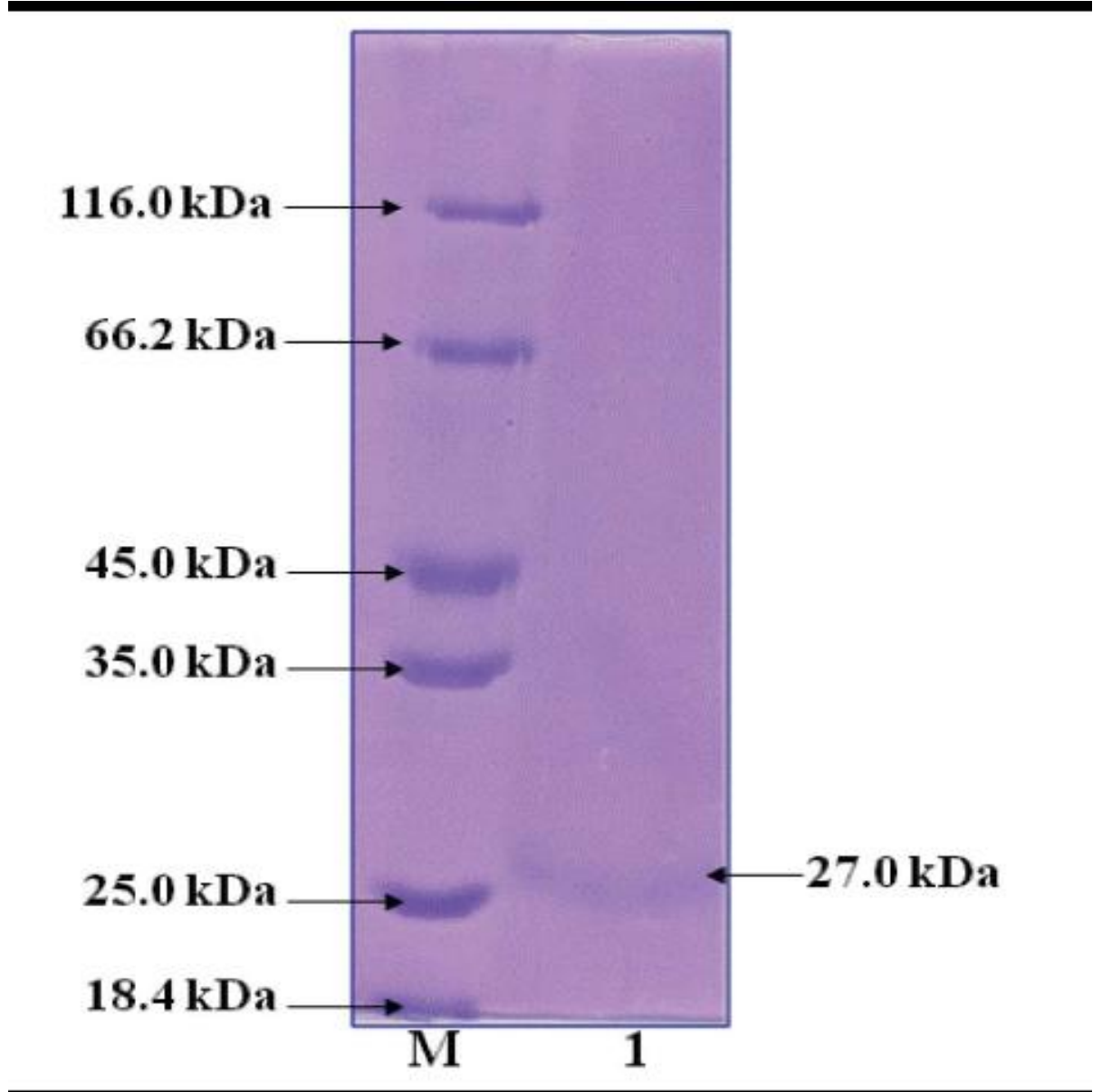


The body fluid or hemolymph of almost all invertebrate species contains agglutinins (Yeaton, 1981, Jayaraj et al., 2008). The presence of agglutinins has also been detected in the mucus as well as in certain tissues however its immunological role is best in the hemolymp (Suzuki and Mori., 1991). Recent studies have shown that purified hemolymp served as opsonin in a few insects and mollusks although a number of studies have demonstrated the presence of humoral agglutinins in several crustacean species. It can be noted that the immunological role of these agglutinins remain unknown and that the carbohydrate specificity of serum agglutinins from crustaceans have been elucidated only in a few species (Jayasree, 2001). In the present study describes bacterial growth inhibition activities and carbohydrate specificity of a naturally occurring protein in the serum of the marine crab Protunus pelagicus.

In 2010, Petnual et al., found the antimicrobial activity of Curcuma longa lectins expressed the minimal inhibitory concentration (MIC) of four microbial species namely Staphylococcus aureus, Pseudomonas aeruginosa, Bacillus subtilis, and Escherichia colli MIC values 0.005, 0.011, 0.002, 0.092 $\mathrm{mg} / \mathrm{l}$ respectively. From the tested strains Pseudomonas aeruginosa shows lowest MIC value 0.002 to be most sensitive to the lectins. In the present study, for $10 \mu \mathrm{g}$ concentration Staphylococcus aureus, shows $7 \mathrm{~mm}$, Pseudomonas aeruginosa $8 \mathrm{~mm}$, Klebsiella pneumonia $6 \mathrm{~mm}$, Bacillus subtilis $7 \mathrm{~mm}$, Escherichia coli $6 \mathrm{~mm}$ and Enterococcus faecalis $4 \mathrm{~mm}$ of inhibition zone. From the tested strains Pseudomonas aeruginosa shows the maximum zone of inhibition.

Lectins have much attention due to specificity of its interaction with the carbohydrates. The change in cell surface carbohydrates in different pathogenic microbes, lectins as a therapeutic tool in clinical diagnostics is well established. Many lectins show antibacterial, antiviral and antifungal activities in vitro and optimising their dosage delivery. Thus lectins can be used anti adhesive agents and prevent the colonization of the microbe and establishment of the infection. The present study indicates that the haemolymph of crabs act as a good source of antibacterial peptide agents and would be replace the existing inadequate and cost effective antibiotics.

\section{References}

Batoy, C.B., Sarmago, J.F., Pilapil, B.C. 1980. Breeding season, sexual maturity and fecundity of blue crab, Portunus pelagicus $(L)$ in selected coastal waters in Leyte and Vicinity, Philippines. Ann. Trop. Res 9: 157-177.

Bauer, A.W., Kirby, W.M.M., Sherris, J.C., Turch, M. 1996. Antibiotic susceptibility testing by a standardizing single disc method. Ameri. Jour. Clinic. Pathol, 45: 493-496.

Boyd, M.R., Gustafson, K.R., McMahon, J.B., Shoemaker, R.H., Mori, T., Gulakowski, R.J., and M.I. Rivera, (1997). Discovery of cyanovirin- $\mathrm{N}$, a novel human immunodeficiency virus- inactivating protein that bind viral surface envelope glycoprotein gp120 potential applications to microbicide development. Antimicrob. Agent Chemother. 41, 1521-1530.

Cole, A.M. 2005. Antimicrobial peptide microbicides targeting HIV. Protein pept, let. 12: 41-47.

Hudson,D.A and Lester, R.J.G. 1994. Parasites and symbionts of wild mud crabs, Scylla serrate (Forskal) of potential significance in aquaculture. Jour.of.Aquaculture 120: 183-199.

Jayaraj SS., Thiagarajan R., Vincent S, and M. Arumugam (2008), Characterization of a natural haemagglutinin from the plasma of marine mussel Pernaviridis. Bull. Europ.Jour. Assoc. Fish pathol. 28: 7684. 
Jayasree S., (2001), Biological properties of a natural agglutinins in the hemolymp of Indian white prawn, Penaeus indicus. $\mathrm{H}$. Milne Edwards. Journ.Of. Aquaculture 194: 245-252.

Joel, D.R., Raj, P.S.S. 1987. Marine crab fisheries around pulcat. Seafood Exp. J.19: 16-24.

Jong Cheon Na., Byung Tae Park, Woo Hyuk Chung, and Ha Hyung Kim. 2011., Molecular Characterization and Mitogenic Activity of a Lectin from purse crab Philyrapisum. Karen Journ. Physiol. Pharmacol 15: 241 - 244.

Laemmli. UK, (1970) Cleavage of structural proteins during the assembly of the head of bacteriophageT4. Nature. 277: 680685.Hansen, J.E., Nielsen, C.M., Nielsen, C., Heegaard, P., and LR. Mathisen (1989), Correlation between carbohydrate structure on the envelope glycoprotein gp120 of HIV-1 and HIV-2 and syncytium inhibition with lectins. AIDS. 3: 635-641.

Lis, H and Sharon, N. 1981. Lectins in higher plants. In: A. Marcus (Ed), the Jour.of. Biochemistry of plants vol.6: 371-447. New York, Academic Press.

Mgaya, Y.D., Muruke, M.H.S., Chande, A.I, Semesi, A.K. 1999. Evaluation of crustacean resources in Bagamoyo District. Proceedings of a workshop on coastal resources of Banamoyo. pp. 5563. Faculty of Science, University of Dares Salaam.

Movafagh, A., Ghanati, K., Amani, D., Mahdavi, S.M., Hashemi, M., Safari, S., Zamani, M. 2013. The structure biology and application of phytohemagglutinin
(PHA) in phytomedicine: with special up to date reference to lectins. Jounal. Of. Paramedicine sci. 4: 80-87.

Petnual, P., Sangvanich, P., and A. Kamchanatat, (2010). A lectins from the rhizomes of turmeric (Curcuma longa) and its antifungal, antibacterial and alphaglucosidase inhibitory activities. Food science and Biotechnology, 19: 907-916.

Ravichandran. S, Sivasubramanian. $\mathrm{K}$ and Anbuchezhian. R.M, 2010. Antimicrobial activity from the Haemolymph of the crab Ocypode macrocera (H. Milne-Edwards 1852). Journal of World Applied Sciences, 11: (5), 578- 581.

Roshan Dinesh Yedery and KudlmulaVenkata Rami Reddy, 2009. Purification and characterization of antibacterial protein from granular haemocytes of Indian mud crab, Scylla serrate, Acta Biochemical Polonica 56: (1), 71-82.

Sing, R.S., Kaur, H.P., Singh, J. 2014. Purification and characterization of a mucin specific myceliallectin from Aspergillus gorakhpuresis. Application for mitogenic and antimicrobial activity. PLoS One. 9: 109265.

Suzuki T, and K. Mori, (1991), Immunolocalization and in vitro secretion of hemolymp lectins of the pearl oyster, Pinctada fucata martensil. Zool. Sci. 8: 23-29.

Yeaton, R.W, (1981). Invertebrate lectins II: Diversity of specificity, biological synthesis and function in recognition. Dev. Comp. Immunol. 5: 535-545.

Yeaton, R.W, (1981). Invertebrate lectins: I. Occurrence. Dev. Comp. Immunol. 5: 391-402.

\section{How to cite this article:}

Selvaraj Chidhambaradhas, Thankaiah Selva Mohan and Stanislaus Mary Josephine Punitha. 2017. Identification and Purification of Antimicrobial Lectins from Marine Crab Protunus pelagicus (Linneus, 1775). Int.J.Curr.Microbiol.App.Sci. 6(6): 2346-2351. doi: https://doi.org/10.20546/ijcmas.2017.606.277 